\title{
STAN PASAR SEBAGAI JAMINAN BERDASARKAN PERJANJIAN TENTANG PEMBERIAN HAK MEMAKAI RUANG (STAN) DI BANK CENTRAL ASIA
}

\author{
Novia Rianti \\ Magister Kenotariatan Fakultas Hukum Universitas Airlangga \\ J1. Dharmawangsa Dalam Selatan, Surabaya \\ E-mail : noviarianti.fh@gmail.com
}

\begin{abstract}
Space rights agreement is a part of lease agreement. Leasing is an agreement that gives a right called individual rights. It is because the right to lease arises from an agreement between one legal subject to another. Thus, this right can only be accountable to the opponent of the contract in accordance with the principle of privity of contrac. A lease agreement aims at providing the right only to use the property, and not to own it. Therefore, lease agreement only gives individual rights, not property rights. On the other hand, as we know, fiduciary provides object guarantees, which is included in constitutum possessorium (the object transferred remains within the control of the fiduciary giver). The air rights, the market stall, from the agreements of rights granting, are clearly included in individual rights, rather than property, which should not be imposed on fiduciary guarantees. This research is conducted by applying doctrinal research. It adapts statute approach, conceptual approach, and case study for its methodological problem approach. This study analyzes the market stall usage rights as an object from the perspective of security laws and Fiduciary on the usage rights upon a market stall by banks. The results of the research showed that by reviewing it further using air rights perspective, the air rights upon a market stall were included in lease rights. The right to use the stall is not property rights, but is an individual right. It is based on the law of lease rights. In addition, the debtor, as the tenant, only controls the leased objects to make use of it, not for the purpose of owning it. In that way, the lease itself does not result in property rights. However, if it is reviewed further based on the air rights, this can be categorized as an object with security laws, because the air rights fulfill the requirements as an object that can be guaranteed. It is because it has economic value and can be transferred, even though it is approved by another party. Since the air rights are individual right, it cannot be used as a guarantee for pawn, mortgage, and Fiduciary.
\end{abstract}

\section{Keywords: Market Stall, Guarantee, Agreement}

\begin{abstract}
Abstrak
Perjanjian pemberian hak memakai ruang merupakan perjanjian sewa-menyewa. Sewamenyewa merupakan perjanjian yang menimbulkan suatu hak yang disebut hak perorangan, hal tersebut dikarenakan hak untuk sewa muncul dari adanya perikatan antara subjek hukum yang satu dengan yang lain, sehingga hak ini hanya dapat dipertanggung jawabkan terhadap lawan sekontraknya saja sesuai dengan asas privity of contrac. Perjanjian sewa-menyewa bertujuan untuk memberikan hak untuk menikmati (memakai) saja, bukan hak milik atas suatu benda. Karena hal tersebutlah Perjanjian sewa menyewa tidak memberikan suatu hak
\end{abstract}


kebendaan, melainkan hanya memiliki hak perorangan. Di sisi lain, seperti yang kita ketahui jaminan fidusia merupakan jaminan kebendaan yang memiliki ciri khusus yaitu constitutum possessorium (benda yang dialihkan tetap dalam berada dalam penguasaan pemberi fidusia). Hak pemakaian ruang (stan) pasar yang berasal dari perjanjian tentang pemberian hak, jelaslah bukan merupakan hak kebendaan tetapi lebih kepada hak perorangan yang seharusnya tidak dapat di bebani dengan jaminan fidusia. Tipe penelitian hukum yang digunakan adalah doctrinal research, dengan metode pendekatan masalah berupa pendekatan peraturan perundang-undangan (Statute Approach), konseptual (Conceptual Approach), dan studi kasus (case study). Penelitian ini menganalisis kedudukan hak memakai ruang (stan) pasar sebagai benda dalam perspektif hukum jaminan dan pembebanan jaminan fidusia atas hak memakai ruang (stan) pasar oleh bank. Dari penelitian tersebut diperoleh hasil Kedudukan hak memakai ruang (stan) pasar merupakan hak sewa jika di tinjau lebih jauh dalam perjanjian hak memakai ruang. Hak memakai ruang (stan) merupakan hak perorangan dan bukan merupakan hak kebendaan dengan pertimbangan bahwa hak memakai ruang tersebut lahir dari sewa menyewa. Selain itu debitor sebagai pihak penyewa hanya menguasai benda yang disewakan untuk mendapat kenikmatan bukan bertujuan untuk memiliki benda tersebut, sehingga sewa menyewa tidak melahirkan hak kebendaan. Namun jika ditinjau lebih jauh hak memakai ruang dapat dikategorikan sebagai benda dalam perspektif hukum jaminan, dikarenakan hak memakai ruang memenuhi syarat sebagai benda yang dapat dijaminkan yaitu memiliki nilai ekonomis dan dapat dialihkan meskipun dengan persetujuan pihak lain. Mengingat hak memakai ruang merupakan hak perorangan, maka hak tersebut tidak dapat dijadikan objek jaminan dalam bentuk Gadai, Hipotek, Hak Tanggungan dan Fidusia.

\section{Kata Kunci : Stan Pasar, Jaminan, Perjanjian}

\section{A. PENDAHULUAN}

Peningkatan laju perekonomian, menjadikan masyarakat berlomba-lomba untuk menciptakan lapangan usaha. Bukan hal yang mudah membuat suatu lapangan usaha, masyarakat membutuhkan ketersediaan modal. Ketersediaan modal tersebut sebagian besar banyak didapat melalui pinjaman atau kredit yang diberikan oleh lembaga perbankan yang biasa disebut Bank. Kepercayaan merupakan unsur yang sangat penting dalam pemberian fasilitas kredit, namun selain kepercayaan terdapat prinsip lain yang dijadikan dasar kreditor (bank) dalam pemberian kredit yaitu Prinsip Kehati-hatian, hal ini tercermin dalam Pasal 2 Undang-Undang Perbankan yaitu perbankan dalam melakukan usahanya berdasarkan demokrasi ekonomi dengan menggunakan prinsip kehati-hatian. Agar kreditor mendapatkan suatu keyakinan dalam memberikan fasilitas kredit, kreditor akan melakukan analisis terhadap kelayakan debitor yang dikenal dengan "prinsip 5C", yaitu:

1. Character (watak dari calon debitor);

2. Capacity (kemampuan untuk melakukan pembayaran);

3. Capital (modal);

4. Collateral (jaminan, yang memiliki hak kebendaan); dan 


\section{Condition of economy (kondisi ekonomi calon debitor). ${ }^{1}$}

Terhadap Jaminan umum sebagaimana dalam Pasal 1131 BW, kreditor merasa kurang di untungkan karena kurang memberikan rasa aman, karena ketentuan jaminan umum diberlakukan terhadap seluruh kreditor jika debitor wanprestasi, sehingga apabila debitor memiliki kreditor lebih dari satu, jika debitor wanprestasi, kekayaan debitor akan dibagi seimbang kepada semua kreditor, hal ini membuat kekawatiran apabila kekayaan debitor tidak mencukupi untuk melunasi utang-utangnya pada semua kreditor. Oleh karena itu diperlukan jaminan tambahan yang disebut jaminan khusus, yaitu jaminan yang timbul dari perjanjian yang dibuat antara kreditor dan debitor yang memberikan jaminan kebendaan ataupun jaminan yang bersifat perorangan. ${ }^{2}$ Perjanjian khusus dapat dibuat jika ada perjanjian awal yang dikenal dengan perjanjian pokok yaitu perjanjian kredit. Perjanjian khusus hanya bersifat tambahan (perjanjian accessoir) yang artinya bergantung pada perjanjian pokoknya berupa perjanjian kredit.

Pelaku usaha kebanyakan lebih suka untuk menjaminkan benda bergerak terutama benda modal yang diikat dengan jaminan fidusia. Hal ini karena benda yang menjadi objek jaminan fidusia masih dikuasai debitor untuk menjalankan usahanya. Maka bagi para pelaku usaha kebanyakan jaminan fidusia dirasa sangat cocok. Jaminan Fidusia awalnya dikenal timbul atas dasar kebutuhan masyarakat akan kredit dengan jaminan benda-benda bergerak, namun benda-benda yang dijaminkan tersebut masih diperlukan debitor untuk rnenjalankan usahanya. ${ }^{3}$ Penyerahan hak milik didalam jaminan fidusia dikenal dengan penyerahan secara constitutum possessorium, yang artinya benda yang dialihkan tetap dalam penguasaan pemilik benda (pemberi fidusia). ${ }^{4}$

Sewa-menyewa merupakan hak yang dikatagorikan sebagai hak perorangan, hal tersebut dikarenakan hak untuk sewa muncul dari adanya suatu perikatan antara subjek hukum yang satu dengan subjek hukum yang lain, sehingga hak ini hanya dapat dipertanggung jawabkan terhadap lawan sekontraknya saja sesuai dengan asas privity of contrac. Tujuan dari perjanjian sewa-menyewa adalah untuk memberikan kenikmatan atas suatu benda dalam arti hanya hak memakai saja, bukan hak milik atas suatu benda. Karena hal tersebutlah perjanjian sewa menyewa hanya memberikan hak perorangan bagi para pihak yang terikat dalam perjanjian tersebut.

Di sisi lain, seperti yang kita ketahui jaminan fidusia merupakan jaminan kebendaan yang memiliki ciri-ciri yaitu benda yang hak kepemilikannya dialihkan tetap dalam berada dalam penguasaan pemilik benda. Hak pemakaian ruang (stan) pasar yang berasal dari

\footnotetext{
${ }^{1}$ Yulianto, Tanggung Jawab Notaris Dalam Membuat Akta Jaminan Kredit Perbankan, Mitra Usaha Abadi, Surabaya: 2004, hlm.4.

${ }^{2}$ Sri Soedewi Masjchoen Sofwan, Hukum Jaminan di Indonesia Pokok-Pokok Hukum Jaminan dan Jaminan Perorangan, Liberty, Yogyakarta: 1980, hlm.46.

${ }^{3}$ Sri Soedewi Masjchoen Sofwan, Hukum Perdata: Hak Jaminan Atas Tanah, Liberty, Yogyakarta: 1981, hlm.75.

${ }^{4}$ Trisadini Prasastinah Usanti dan Leonora Bakarbessy, Hukum Jaminan, Revaka Petra Media, Surabaya: 2013 , hlm.88.
} 
perjanjian tentang pemberian hak, jelaslah bukan merupakan hak kebendaan melainkan hak perorangan yang seharusnya tidak dapat dijaminkan dengan jaminan fidusia.

Dalam praktiknya di Bank Central Asia, hak memakai ruang (stan) pasar yang berasal dari perjanjian pemberian hak, dapat dipergunakan sebagai jaminan kredit perbankan yang diikat dengan jaminan Fidusia. Secara teori seharusnya stan pasar bukan merupakan objek jaminan fidusia, hal ini mengakibatkan saat ini terjadi permasalahan hukum diantara Pihak Kreditor (BCA) dengan debitor dikarenakan debitor tidak dapat melakukan pembayaran atas utangnya.

\section{B. RUMUSAN PERMASALAHAN}

Berdasarkan uraian latar belakang diatas maka yang menjadi permasalahan dalam tulisan ini adalah: a) Kedudukan hak memakai ruang (stan) pasar sebagai benda dalam perspektif hukum jaminan; dan b) Pembebanan jaminan fidusia atas hak memakai ruang (stan) pasar oleh bank.

\section{METODE PENELITIAN}

Penelitian ini merupakan penelitian hukum, maka metode yang digunakan adalah metode penelitian hukum (Doctrinal Research). ${ }^{5}$ Penelitian hukum merupakan suatu kegiatan know-how dalam ilmu hukum, bukan sekedar know about, sehingga tujuan dari penelitian hukum ini adalah untuk memecahkan isu hukum yang dihadapi. ${ }^{6}$ Metode penelitian hukum adalah cara atau suatu proses untuk menemukan aturan hukum, prinsip-prinsip hukum, atau doktrin-doktrin hukum guna menjawab isu hukum yang dihadapi. Hal ini sesuai dengan karakter ilmu hukum yang bersifat preskriptif dan terapan. Mengingat karakteristik keilmuan tersebut, ilmu hukum selalu berkaitan dengan apa yang seyogyanya dan apa yang seharusnya.

Sumber bahan hukum yang digunakan dalam penulisan tesis ini terdiri dari bahan hukum primer dan bahan hukum sekunder. Bahan hukum primer terdiri dari perundangundangan dan putusan-putusan hakim (yurisprudensi). Bahan hukum sekunder berupa Publikasi tentang hukum yang meliputi buku-buku teks, kamus-kamus hukum, jurnal-jurnal hukum, dan komentar atas putusan pengadilan. ${ }^{7}$

\section{PEMBAHASAN}

1. Kedudukan Hak Memakai Ruang (Stan) Pasar sebagai Benda dalam Perspektif Hukum Jaminan

\section{a. Hak Memakai Ruang (Stan) Pasar sebagai Benda dalam Objek Jaminan}

Benda merupakan sesuatu hal yang penting bagi keberlangsungan hidup manusia, hal ini dapat dilihat dari setiap manusia yang mengejar pemenuhan

\footnotetext{
${ }^{5}$ Peter Mahmud Marzuki, Penelitian Hukum (Edisi Revisi), Kencana, Jakarta: 2005, hlm. 60.

${ }^{6}$ Ibid.

${ }^{7}$ Ibid., h.181.
} 
kebutuhannya dengan mencari benda untuk dimiliki supaya kesejahteraannya kian meningkat. Bahkan ketika seseorang telah memiliki benda yang ia inginkan, suatu saat benda tersebut akan dirampas oleh orang lain, ia akan mempertahankan setiap benda yang telah dimilikinya. Lantas apa yang dimaksud dengan benda?

Hukum Benda diatur dalam Buku II BW. Definisi mengenai benda terdapat dalam pasal 499 BW sebagai berikut: "menurut paham undang-undang yang dinamakan kebendaan ialah tiap-tiap barang dan tiap-tiap hak yang dapat dikuasai oleh hak milik." Benda adalah segala sesuatu yang dapat dijadikan objek hak milik sesuai pasal $499 \mathrm{BW}$.

Dalam definisi Pasal 499 BW, mencerminkan bahwa benda memiliki pengertian yang bersifat luas yaiutu meliputi benda berwujud dan juga benda tidak berwujud. Tetapi Jika merujuk kata barang, mempunyai pengertian yang lebih sempit karena merujuk pada benda yang berwujud. Adapun benda yang tidak berwujud identik dengan hak, misalnya saja piutang-piutang atau penagihan-penagihan. ${ }^{8}$

BW mengatur benda berdasarkan golongannya, penggologan benda dalam BW nampak sangat rinci bahkan nyaris lengkap. Pembagian tersebut misalnya: ${ }^{9}$

1) benda berwujud-benda tak berwujud;

2) benda bergerak- benda tak bergerak;

3) benda habis pakai-benda tidak habis pakai;

4) benda yang sudah ada-benda yang masih akan ada;

5) benda yang dapat dibagi-benda yang tidak dapat dibagi;

6) benda dalam perdagangan-benda diluar perdagangan;

7) benda yang dapat diganti-benda yang tidak dapat diganti; dan

8) benda bertuan-benda tidak bertuan.

Pembagian benda bergerak dan benda tidak bergerak merupakan penggolongan benda yang sangat penting dalam ruang lingkup keberlakuan BW. Hal ini disebabkan bahwa pembagian benda bergerak dan benda tidak bergerak mempunyai pengaruh dalam banyak bidang. Adapun bidang-bidang yang perlu ditelaah adalah sebagai berikut:

1) Dalam bidang Bezit bahwa menguasai secara nyata benda bergerak, maka berlakulah ketentuan Pasal 1977 BW, dimana ditetapkan bahwa seseorang yang menguasai benda bergerak dianggap sebagai pemilik. Untuk benda tidak bergerak tidak berlaku ketentuan Pasal 1977 BW.

\footnotetext{
${ }^{8}$ Frieda Husni Hasbullah, Hukum Kebendaan Perdata Hak-Hak Yang Memberi Kenikmatan Jilid I, Cetakan KeIII, Ind-Hill Co, Jakarta: 2002, hlm. 19-20.

9 Moch. Isnaeni, Hukum Jaminan Kebendaan (Eksistensi, Fungsi, dan Pengaturan), LaksBang Pressindo, Yogyakarta: 2016, hlm. 2.
} 
2) Dalam bidang Lavering, bahwa dalam penyerahan dibagi atas 2 (dua) macam penyerahan yaitu penyerahan nyata dan penyerahan yuridis. Pada waktu seseorang hendak memindahkan hak milik suatu benda bergerak maka yang bersangkutan menyerahkan pada pihak lain maka seketika itu pula baik penyerahan nyata dan penyerahan yuridis jatuh bersamaan. Berbeda lagi dalam hal yang dipindahkan adalah benda tidak bergerak, maka antara penyerahan nyata dan penyerahan yuridis akan nampak bertahap baik dalam waktu ataupun tindakannya.

3) Dalam bidang Verjaring, bahwa benda tidak bergerak tidak mengenal daluarsa sedangkan benda bergerak daluarsanya dalam di lihat dalam Pasal 1963 BW.

4) Dalam bidang Bezwaring, bahwa kalau yang dijaminkan berupa benda bergerak maka lembaga yang disediakan oleh BW adalah gadai,

5) Dalam bidang Beslag, berdasarkan prosedur sesuai aturan-aturannya melalui eksekusi, maka benda bergerak harus dilakukan terlebih dahulu jika dirasa tidak cukup melunasi utangnya maka dapat melakukan sita benda tidak bergerak.

Yang dimaksud benda dalam lapangan hukum benda dan dalam lapangan hukum perikatan itu berbeda. Benda dalam lapangan hukum benda, bahwa terhadap benda dapat dilakukan penyerahan dan umumnya dapat menjadi objek dari hak milik. Akan tetapi, apabila benda bukan dalam arti demikian maka itu tak berarti bahwa tidak dapat menjadi objek dari pada hukum perutangan. Apabila merujuk pada uraian tersebut, maka hak memakai ruang (stan) yang dalam bentuk hak sewa- menyewa atas ruangan merupakan bagian yang tidak terpisah dari gedung atau bangunan, dapat dikategorikan 'Benda' dalam lapangan hukum perikatan.

Selain itu sesuatu dapat dijadikan objek jaminan sepanjang memiliki nilai ekonomis dan dapat dipindah tangankan. Nilai ekonomis hak memakai ruang (stand) dapat dilihat dari tujuannya untuk menyewa stand yang ada nilai ekonomis, karena harga sewa bisa meningkat dari waktu kewaktu seiring perkembangan lokasi bisnis bangunan tersebut, dan juga hak memakai ruang ini dimungkinkan untuk dialihkan sepanjang terdapat persetujuan dari pemilik bangunan.

\section{b. Hak Kebendaan dan Hak Perorangan dalam Hukum Jaminan}

Berdasarkan uraian tersebut diatas ruang lingkup hak jaminan dibagi atas jaminan umum dan jaminan khusus. Untuk Jaminan khusus dibagi menjadi 2 (dua), yaitu : ${ }^{10}$

\section{1) Jaminan Perorangan}

Jaminan Perorangan berasal dari perjanjian jaminan antara kreditor (bank) dan pihak ketiga sebagai penjamin debitor. Perjanjian jaminan perorangan memiliki ciri sebagai hak relatif, yaitu hak yang hanya dapat dipertahankan terhadap orang tertentu yang terikat dalam perjanjian. Jaminan perorangan meliputi: borg, tanggung-

${ }^{10}$ Djuhaendah Hasan dan Salmidjas Salam, Aspek Hukum Hak Jaminan Perorangan dan Kebendaan, Jakarta: 2000, hlm. 214. 
menanggung (tanggung renteng), dan garansi bank. Jaminan Perorangan memiliki ciriciri sebagai berikut:

a) Bersifat relatif, yaitu hanya bisa ditegakkan pada pihak tertentu saja yang terikat pada perjanjian.

b) Tidak ada asas Droit de suite, yaitu hak tidak mengikuti kemanapun benda tersebut beralih.

c) Kedudukan antara pemegang hak perorangan yang satu dengan yang lain adalah sederajat, tidak ada yang didahulukan.

d) Berkedudukan sebagai kreditor konkuren.

e) Gugatnya disebut gugatan perorangan.

2) Jaminan Kebendaan

Hak kebendaan (zakelijkrecht) ialah hak mutlak atas sesuatu benda dan dapat dipertahankan terhadap siapa pun. Jaminan kebendaan merupakan hak mutlak (absolut) atas suatu benda tertentu yang menjadi objek jaminan suatu hutang. Hak kebendaan dapat dipertahankan terhadap siapapun. Dengan mempunyai berbagai kelebihan, yaitu antara lain sifat absolut dimana dapat dipertahankan terhadap siapapun, memiliki droit de preference (didahulukan), droit de suite (mengikuti benda tersebut berada), dan juga mengandung makna asas spesialitas dan publisitas, yang lebih memberikan kedudukan dan hak istimewa bagi pemegang hak tersebut (kreditor). ${ }^{11}$

Jika berdasarkan penjelasan tersebut maka hak memakai ruang (stan) pasar merupakan hak perorangan yang memberikan kenimkatan untuk menempati, sehingga hak yang dipeoleh merupakan hak perorangan yang tidak memberikan suatu hak kebendaan jika stan pasar tersebut dijadikan suatu jaminan dalam kredit.

\section{c. Perjanjian Pemberian Hak Memakai Ruang (Stan) berdasarkan Asas Kebebasan Berkontrak}

Asas hukum bisa muncul dari pandangan maupun dalam kehidupan sosial yang kemudian di pilih oleh pembuat undang-undang sehingga menjadi aturan hukum. Menurut Prof. Peter Mahmud Marzuki, aturan-aturan hukum yang mempunyai kontrak sebenarnya penjelmaan dari dasar-dasar filosofi yang terdapat pada asas-asas hukum secara umum. ${ }^{12}$ Asas hukum menjadi landasan norma menjadi alat uji bagi norma hukum yang ada, dalam arti norma hukum tersebut pada akhirnya harus dapat dikembalikan pada asas hukum yang menjiwainya. ${ }^{13}$

Dalam bidang hukum perjanjian dikenal berbagai asas yang melandasi. Asasasas dalam perjanjian dalam UNIDROIT dapat dijelaskan sebagai berikut: ${ }^{14}$

\footnotetext{
${ }^{11}$ Djuhaendah Hasan dan Salmidjas Salam, Aspek Hukum Hak Jaminan Perorangan dan Kebendaan, Jakarta: 2000, hlm. 214.

${ }^{12}$ Peter Mahmud Marzuki, "Batas-Batas Kebebasan Berkontrak”, Yuridika, No. 3, Vol.18, 2003, hlm.196.

${ }^{13}$ Ibid, h. 196

${ }^{14}$ Taryana Soenandar, Prinsip-prinsip Unidroit, Sinar Grafika, Jakarta: 2004, hlm.36.
} 
1) Asas kebebasan berkontrak;

2) Asas itikad baik dan transaksi jujur;

3) Asas diakuinya kebiasaan transaksi bisnis dinegara setempat;

4) Asas kesepakatan melalui penawaran dan penerimaan atau melalui tindakan;

5) Asas larangan bernegosiasi dengan itikad baik;

6) Asas kewajiban menjaga kerahasiaan;

7) Asas perlindungan pihak lemah dari syarat-syarat baku;

8) Asas syarat sah kontrak;

9) Asas dapat dibatalkannya kontrak bila mengandung perbedaan besar;

10) Asas contra proferentem dalam penafsiran kontrak baku;

11) Asas menghormati kontrak ketika terjadi kesulitan

12) Asas pembebasan tanggung jawab dalam keadaan memaksa.

Didalam hukum perjanjian/hukum kontrak terdapat empat asas yang utama, yaitu:

1) Asas kebebasan berkontrak;

2) Asas konsensualisme;

3) Asas pacta sun servanda;

4) Asas itikad baik.

Asas-asas tersebut diatas yang menjadi dasar para pihak yang membuat suatu perjanjian dalam menentukan dan membuat suatu kontrak. Dengan demikian dapat dipahami asas-asas diatas merupakan hal penting yang harus diperhatikan bagi pembuat kontrak sehingga tujuan dari suatu kesepakatan dapat tercapai dan terlaksana sebagaimana yang diinginkan oleh para pihak.

Beranjak dari asas-asas perjanjian yang telah dijabarkan diatas, maka dalam penulisan ini di jelaskan lebih lanjut mengenai Asas kebebasan berkontrak dalam pelaksanaan perjanjian pemberian hak memakai ruang (stan). Asas kebebasan berkontrak mengandung pengertian bahwa setiap orang memiliki kebebasan untuk mengikatkan dirinya pada orang lain. Dalam asas kebebasan berkontrak, tidak hanya mengakui jenis-jenis perjanjian yang telah diatur atau ada di dalam undang-undang tetapi juga mengakui terhadap perjanjian yang dibuat para pihak sekalipun jenis perjanjian tersebut tidak diatur dalam undang-undang. ${ }^{15}$

Kemudian jika diantara PT Prosam Plano \& Co dan pedagang di pasar atom membuat suatu perjanjian yang diberi nama "Perjanjian tentang Pemberian Hak Memakai Ruang (Stan) yang dibuat dihadapan notaris di Surabaya, yang kemudian atas dasar perjanjian tersebut PT Prosam Plano \& Co mengeluarkan Sertipikat sebagai

15 Ridwan Khairandy, Itikad Baik dalam Kebebasan Berkontrak, Pascasarjana Fakultas Hukum Universitas Indonesia, Yogayakarta: 2003, hlm.124 
Tanda Bukti Hak untuk memakai ruang (stan) yang selanjutnya dijadikan objek jaminan dapat dilakukan dengan merujuk Pasal 1320 BW dan Pasal 1338 BW. Dimana ketentuan pasal tersebut menganut asas kebebasan berkontrak dimana orang leluasa untuk membuat perjanjian apa saja dan mengikat kedua belah pihak, asal perjanjian tersebut dibuat tidak melanggar undang-undang, mengganggu ketertiban umum dan kesusilaan.

Terkait perjanjian pemberian hak untuk memakai ruang, maka menurut penulis perlu dibahas pula mengenai perjanjian sewa menyewa yang mendasari timbulnya hak memakai ruang (stan).

Perjanjian sewa menyewa diatur dalam buku III BW dimana dalam perjanjian sewa menyewa Pihak penyewa hanya diberikan hak untuk menikmati saja (hanya menempati stan pasar). Perjanjian sewa menyewa juga merupakan perjanjian timbal balik, dimana pihak yang satu berhak atas prestasi dan pihak yang lain wajib menjalankan prestasi berdasarkan kesepakatan para pihak dan merupakan salah satu jenis perjanjian yang sering terjadi dalam kehidupan sehari-hari. ${ }^{16}$ Berdasarkan pasal 1548 BW, yang dimaksud sewa menyewa adalah perjanjian dimana pihak yang satu mengikatkan dirinya untuk memberikan kepada pihak yang lain kenikmatan dari suatu barang selama suatu waktu tertentu dengan pembayaran sesuatu harga yang telah disepakati. $^{17}$

Berdasarkan perjanjian sewa menyewa tersebut di atas yang telah di uraikan timbullah hak perorangan (persoonlijk) yaitu semua hak yang timbul karena adanya hubungan perikatan dalam hal ini utang piutang yang hanya dapat dipertahankan untuk sementara orang-orang tertentu saja. Sehingga tentunya dalam hal ini posisi BCA sebagai kreditor lemah dengan memegang hak sewa atas ruang (stan) pasar sebagai jaminan. Karenanya perlu di analisis tentang hak sewa atas ruang (stan) pasar dari pranata hukum jaminan. Kemudian yang menjadi pertanyaan, hak sewa atas stand pasar dapat dijadikan jaminan yang diikat dalam suatu pranata jaminan yang bersifat kebendaan.

Jika para pihak memberikan nama perjanjian pemberian hak memakai ruang (stand) maka sejatinya didalam hukum pertanahan konsep tersebut disebut dengan Hak Sewa Atas Bangunan (HSAB), yaitu bahwa penyewa menyewa bangunan diatas tanah hak orang lain dengan membayar sejumlah uang sewa dan dalam jangka waktu yang tertentu yag disepakati oleh pemilik bangunan dengan penyewa bangunan. Berbeda dengan Hak Sewa Untuk Bangunan (HSUB) dikarenakan apabila hak sewa untuk bangunan, pemilik tanah menyerahkan tanahnya dalam keadaan kosong kepada penyewa agar penyewa bisa mendirikan bangunan diatas tanah tersebut, tentunya

\footnotetext{
${ }^{16}$ Wirjono Prodjodikoro, Hukum Perjanjian dan Perikatan, Pradya Paramita, Jakarta: 1987, hlm. 53

${ }^{17}$ Subekti, Hukum Perjanjian, Intermasa, Jakarta: 1992, hlm.123.
} 
ketentuan sewa diikuti dengan pembayaran sejumlah uang sewa tertentu dalam jangka waktu tertentu yang disepakati oleh pemilik tanah dan pemegang hak sewa untuk bangunan.

\section{d. Hak Memakai Ruang (Stand) dalam Jaminan Kebendaan di Indonesia}

Pada dasarnya harta kekayaan seseorang merupakan jaminan dari utangutangnya sebagaimana dinyatakan di dalam Pasal 1131 BW dan Pasal 1132 BW. Tentu jika mengacu pada ketentuan tersebut maka jaminan yang diberikan masih bersifat umum karena jaminan yang diberikan adalah untuk semua kepentingan kreditor. Namun selain jaminan yang bersifat umum, undang-undang juga mengatur jaminan yang bersifat khusus. Jenis jaminan kredit dapat dikelompokkan menurut sifatnya, menurut objeknya, berdasarkan penguasaan benda dan lembaga jaminan yang membebaninya. Pembedaan terhadap penggolongan jenis-jenis benda membawa banyak perbedaan, adapun perbedaan itu dapat dilihat dari salah satu hal yaitu penjaminan (bezwaring).

Pembebanan jaminan atas benda memiliki lembaga jaminan yang bisa berbedabeda, hal tersebut bergantung pada jenis yang ditentukan dengan macam benda yang dijadikan objek jaminan. Terhadap benda bergerak maka oleh BW mengkategorikan bendatersebut dapat dibebani dengan jaminan gadai (Pand), sebagaimana diatur dalam Pasal 1150-1160 BW. Sedangkan untuk benda yang tidak bergerak maka lembaga jaminan yang dipergunakan dahulunya adalah hipotek sebagaimana diatur dalam Pasal 1162-1232 BW. Kemudian sesuai dengan kebutuhan dan perkembangan jaman maka muncullah jaminan diluar BW Hak Tanggungan sesuai Undang-Undang Nomor 4 Tahun 1996 tentang Hak Tanggungan atas tanah beserta benda-benda yang berkaitan dengan tanah selanjutnya disebut UU Hak Tanggungan, yang mengambil alih kewenangan jaminan tanah yang awalnya diatur dalam BW sebagai jaminan hipotek. Selain itu terbentulah Undang-Undang Nomor 42 Tahun 1999 tentang Fidusia selanjutnya disebut UU Fidusia yang mengatur jaminan benda bergerak khususnya benda modal.

Lembaga jaminan yang tersebut diatas merupakan jaminan khusus yang objeknya adalah benda tertentu (khusus) milik debitor atau pihak ketiga dan diperuntukkan bagi kreditor tertentu pula. Jaminan khusus disediakan untuk mencegah risiko dikemudian hari dan untuk mencegah kreditor hanya mendapatkan jaminan umum yang mengacu pada ketentuan Pasal 1131 BW. Satu-persatu lembaga jaminan tersebut dapat dijelaskan sebagai berikut:

1) Jaminan Gadai

Istilah "gadai" merupakan terjemahan dari kata pand atau vuistpand (bahasa Belanda), pledge atau pawn (bahasa Inggris), pfand atau faustpfand (bahasa 
Jerman). Selain itu dalam hukum adat istilah gadai ini disebut dengan cekelan. ${ }^{18}$ Dalam ketentuan gadai tidak ada satu pasal yang menyatakan bahwa gadai adalah hak kebendaan, namun pembuktian gadai merupakan hak kebendaan dapat di cermati dari Pasal 1150 BW dan Pasal 1152 ayat (3) BW.

Berdasarkan ketentuan dalam Pasal 1150 BW dan pasal-pasal lainnya dalam BW, gadai memiliki ciri-ciri dan sifat sebagai berikut: ${ }^{19}$

a) Objek gadai adalah benda yang bergerak, baik benda bergerak berwujud maupun benda bergerak yang tidak berwujud.

b) Gadai merupakan hak kebendaan, karenanya walaupun barang-barang yang digadaikan tersebut beralih atau dialihkan kepada orang lain, barangbarang yang digadaikan tersebut tetap atau terus mengikuti kepada siapapun objek barang-barang yang digadaikan itu berada (droit de suite). Apabila barang-barang yang digadaikan itu hilang atau dicuri orang lain, maka kreditor pemegang gadai berhak untuk menuntut kembali.

c) Hak dalam gadai yaitu de preference, artinya gadai memberikan kedudukan diutamakan kepada kreditor pemegang hak gadai.

d) Benda yang digadaikan harus berada dibawah penguasaan kreditor pemegang gadai atau pihak ketiga untuk dan atas nama pemegang gadai.

e) Gadai bersifat Accessoir pada perjanjian pokoknya, artinya eksistensi gadai bergantung pada perjanjian pokoknya (perjanjian kredit);

f) Gadai mempunyai sifat tidak dapat dibagi-bagi, yaitu membebani secara utuh objek kebendaan atau barang-barang yang digadaikan, bahwa apabila telah dilunasinya sebagian dari utang debitor yang dijamin, maka tidak berarti benda yang dijaminkan dapat dikurangi, melainkan hak gadai itu tetap membebani keseluruhan objek benda yang digadaikan untuk sisa utang yang belum dilunasi.

Berdasarkan uraian tersebut di atas, bahwa perjanjian hak sewa atas stan pasar, tidak dapat dikategorikan sebagai objek yang dapat di bebani dengan menggunakan lembaga jaminan gadai. Hal ini dikarenakan hak sewa atas stand pasar tidak dapat secara tegas dikategorikan sebagai benda bergerak, selain itu didalam gadai terdapat ketentuan dimana objek yang digadaikan wajib berada dalam kekuasaan penerima gadai, sedangkan hak sewa stand pasar tidak dapat diserahkan kepada kreditor karena pemanfaatan stand pasar masih digunakan debitor untuk berjualan sehari-harinya.

2) Jaminan Hipotek

\footnotetext{
${ }^{18}$ Rachmadi Usman, Hukum Jaminan Keperdataan, Sinar Grafika, Jakarta: 2016, hlm.104.

${ }^{19}$ Ibid, h. 108
} 
Definisi hipotek dinyatakan dalam Pasal 1162 BW yaitu Hipotek adalah suatu hak kebendaan atas benda-benda tidak bergerak, untuk mengambil penggantian dari padanya bagi pelunasan suatu perikatan. Objek hipotek adalah berupa kapal yang berukuran paling sedikit $20 \mathrm{~m}^{3}$ isi kotor dan sudah terdaftar menurut ketentuan Pasal 314 KUHD jo. Pasal 60 Undang-Undang Nomor 17 Tahun 2008 tentang Pelayaran (UU Pelayaran).

Menurut penulis lembaga jaminan hipotek juga tidak dapat digunakan dalam hal hak sewa atas stand pasar yang dijadikan jaminan, karena hak sewa hanyalah hak menikmati yang bukan merupakan pemilik langsung dari objek bangunan. Selain itu didalam UU Pelayaran telah jelas menyebutkan objek hipotek adalah kapal dengan volume $20 \mathrm{~m}^{3}$.

\section{3) Hak Tanggungan}

Hak Tanggungan merupakan amanat dari Pasal 51 UUPA, bahwa hak tanggungan dapat dibebankan pada hak milik, hak guna usaha, hak guna bangunan sebagaimana diatur dengan undang-undang. Keberdaan Hak tanggungan dimaksudkan sebagai pengganti lembaga dan ketentuan hipotek sebagaimana diatur dalam Buku II BW. Dengan diundangkannya UU Hak Tanggungan maka tanah beserta benda-benda yang berkaitan dengan tanah tidak lagi merupakan objek hipotek tetapi sudah menjadi objek dari Hak Tanggungan.

Ketentuan Objek hak tanggungan terdapat pada beberapa pasal yaitu Pasal 4 UU Hak Tanggungan, Pasal 10 ayat (3) UU Hak Tanggungan dan Pasal 27 UU Hak Tanggungan jo. Pasal 47 Undang-undang nomor 20 tahun 2011 tentang rumah susun, yaitu hak milik, hak guna usaha, hak guna bangunan, hak pakai atas tanah negara (dengan syarat wajib di daftar dan dapat dipindah tangankan), hak pakai atas tanah hak milik, bangunan rumah susun dan hak milik atas satuan rumah susun yang berdiri diatas tanah HM, HGB, atau hak pakai yang diberikan oleh negara, hak lama (petok D), dan hak atas tanah yang berasal dari konversi hak lama yang telah memenuhi syarat untuk didaftarkan akan tetapi pendaftarannya belum dilakukan.

Berdasarkan uraian tersebut di atas mengenai hak tanggungan maka jelas hak sewa atas stand pasar bukan merupakan suatu bentuk hak atas tanah yang dapat dibebeni dengan hak tanggungan.

4) Jaminan Fidusia

Jaminan fidusia merupakan jaminan yang muncul dari adanya perkembangan benda dalam masyarakat. Masyarakat khusus nya para pelaku usaha memerlukan suatu lembaga jaminan yang dapat memberikan jaminan tanpa menahan benda jaminan tersebut, karena benda tersebut dapat dipergunakan sebagai benda modal bagi para pelaku usaha. Dalam jaminan fidusia diantara debitor dengan kreditor akan dibuat suatu kesepakatan dimana debitor akan mengalihkan kepemilikan atas 
suatu benda sebagai jaminan utangnya, namun dengan kesepakatan bahwa debitor tetap akan menguasai secara fisik benda tersebut dan kreditor akan mengalihkan kembali kepemilikan tersebut apabila utangnya telah dibayar lunas. ${ }^{20}$

Awalnya yag menjadi objek jaminan fidusia terbatas pada benda bergerak seperti benda-benda modal (persediaan), peralatan mesin, dan kendaraan bermotor dan lain-lain. Namun semakin mengikuti perkembangan dalam masyarakat akan kebutuhan pinjaman, didalam UU Fidusia diaturlah objek jaminan fidusia tidak hanya benda bergerak namun juga benda bergerak yang berwujud, benda bergerak yang tidak berwujud dan benda tidak bergerak yang tidak dapat dibebani dengan Hak Tanggungan. Dalam Pasal 1 angka 4 UU Fidusia memberikan definisi benda yang menjadi objek jaminan fidusia sebagai berikut "Benda adalah segala sesuatu yang dapat dimiliki dan dialihkan, baik yang berwujud maupun yang tidak berwujud, yang terdaftar maupun yang tidak terdaftar, yang bergerak maupun yang tidak bergerak yang tidak dapat dibebani hak tanggungan atau hipotek". ${ }^{21}$

Dari keempat lembaga jaminan diantara gadai, hipotek, hak tanggungan dan fidusia maka menurut penulis tidak ada yang cocok digunakan untuk hak memakai ruang (stand) pasar. Undang-undang fidusia tidak secara tegas memasukkan hak sewa kedalam definisi benda, namun jika dicermati lebih definisi benda menurut fidusia yaitu kata-kata "segala sesuatu yang dapat dimiliki dan dialihkan", maka penulis menafsirkan bahwa syarat "sesuatu" dapat dikategorikan sebagai benda yang bisa difidusiakan adalah benda yang dapat dikuasai oleh hak milik dan dapat dialihkan serta memiliki nilai ekonomis. Namun sesungguhnya ketentuan hak sewa yang dijadikan jaminan fidusia nampaknya kurang memiliki dasar hukum atau alasan yang kuat. karena pada dasarnya hak sewa digolongkan sebagai suatu hak perorangan, dimana hak tersebut timbul karena digantungkan pada adanya hubungan hukum antara seseorang dengan orang lain terkait pemakaian suatu benda. Dalam faktanya tidak sedikit bank yang menggunakan jaminan fidusia untuk mengikat hak sewa atas stand pasar sebagai jaminan kredit.

Pada tahun 2005, Direktur Jendral Administrasi Hukum Umum Departemen Hukum dan Hak Asasi Manusia telah mengeluarkan Surat Edaran Nomor : C.HT.01.10-22 tertanggal 15 Maret 2015 tentang standarisasi prosedur pendaftaran fidusia (selanjutnya disebut SE No. C.HT.01.10-22). Pada bagian angka 2 dinyatakan ketentuan sebagai berikut: "Khusus tentang pengecekan data atas benda yang menjadi objek jaminan fidusia, kantor pendaftaran fidusia harus dapat membedakan antara hak kebendaan dan hak perorangan. Oleh karena objek jaminan fidusia bersifat kebendaan/agunan atas kebendaan atau jaminan kebendaan. Sehingga tercermin

${ }^{20}$ Fred B.G Tumbuan, Mencermati Pokok-Pokok RUU Jaminan Fidusia, Newsletter Nomor 38 Tahun X, Yayasan Pusat Pengkajian Hukum, Jakarta: 1999, hlm.14.

${ }^{21}$ Undang-undang Republik Indonesia Nomor 42 Tahun 1999 tentang Jaminan Fidusia, Lembaran Negara Republik Indonesia Tahun 1999 Nomor 168, Tambahan Lembaran Negara Repubik Indonesia Nomor 3889. 
proyek, sewa, kontrak, atau pinjam pakai, serta hak perorangan lainnya bukan merupakan pengertian benda yang menjadi objek jaminan fidusia".

Berdasarkan uraian tersebut diatas penulis berpendapat terdapat risiko apabila pengikatan hak sewa atas stand pasar dilakukan dengan jaminan fidusia karena kedudukan hak sewa sebagai objek jaminan tidak didukung dengan aturan hukum yang jelas.

\section{Pembebanan Jaminan Fidusia Atas Hak Memakai Ruang (Stan) Pasar oleh Bank}

\section{a. Pembebanan Hak Memakai Ruang (Stan) Pasar sebagai Objek Jaminan Fidusia}

Pemberian kredit yang dilakukan oleh Bank BCA Cabang Surabaya mengacu pada ketentuan aturan-aturan yang telah ditetapkan BCA dan UU Perbankan, serta peraturan-peraturan yang dikeluarkan oleh BI dan instansi-instansi pemerintah lainnya. $^{22}$ Pelaksanaan pemberian kredit di BCA melalui beberapa proses, yaitu permohonan kredit dimana debitor harus melakukan pengajuan kredit modal kerja dengan membuat suatu data pengajuan yang isinya meliputi latar belakang usaha, data kepemilikan usaha, Surat Ijin Usaha Perdagangan, Nomor Pokok Wajib Pajak, laporan keuangan selama 3 bulan terakhir, pinjaman yang dibutuhkan dan data penggunaan pinjaman. Jika syarat telah dipenuhi, kemudian bagian administrasi kredit akan memberikan berkas permohonan kepada Bagian Account Officer, yang kemudian akan diserahkan ke pejabat yang berwenang. Berkas yang telah diserahkan kepada pejabat pemutus kemudian data tersebut akan dikelola oleh admin kredit, setelah berkas sesuai menurut pejabat yang berwenang dan disetujui, maka selanjutnya bank akan menunjuk notaris untuk memastikan apakah data tersebut sesuai untuk dijadikan jaminan, semisal jika jaminan berupa tanah maka notaris akan melakukan cheking tanah tersebut ke kantor pertanahan, jika data semua sudah sesuai notaris akan membuat pengikatan perjanjian kredit, yang kemudian akan dibuat perjanjian jaminan kebendaan. Dokumen yang diperlukan oleh bank dalam rangka menjadikan hak memakai ruang sebagai jaminan adalah sebagai berikut:

1) Asli salinan akta perjanjian pemberian hak memakai ruang (stand), yang dibuat antara pemilik bangunan dan kios dengan penyewa;

2) Asli surat persetujuan dari pemilik bangunan dan kios, yang memuat antara lain:

a) Persetujuan dari pemilik bahwa hak memakai ruang (stand) tersebut menjadi jaminan bank.

b) Persetujuan bahwa apabila si penyewa lalai memenuhi kewajibannya kepada bank, maka bank berhak mengalihkan hak sewa kepada pihak lain.

3) Asli bukti pembayaran pelunasan sisa harga sewa yang telah dibayar oleh penyewa

\footnotetext{
${ }^{22}$ Wawancara dengan Staff Legal BCA Cabang Surabaya, 5 November 2018.
} 
Proses pembebanan jaminan fidusia meliputi beberapa rangkaian kegiatan yang kesemuanya harus dilakukan. Hal ini berkaitan Berikut akan diuraikan mengenai tahapan pembebanan jaminan fidusia :

a) Tahap Perjanjian Pinjam-menunjam (perjanjian Kredit)

b) Pembuatan Akta Pembebanan Jaminan Fidusia

c) Tahap Pendaftaran Jaminan Fidusia

\section{b. Penyelesaian atas Wanprestasi yang dilakukan debitor}

Perjanjian kredit bank merupakan perjanjian pokok dan perjanjian fidusia merupakan perjanjian tambahan atau ikutan (assessoir). Pada masing-masing perjanjian tersebut terdapat kewajiban untuk melaksanakan prestasi sesuai dengan yang diperjanjikan. Pada situasi yang normal antara prestasi dan kontra prestasi akan saling bertukar, namun pada kondisi tertentu pertukaran prestasi tidak berjalan sebagaimana mestinya sehingga muncul peristiwa yang disebut wanprestasi. ${ }^{23}$ Kadang kala dalam pemberian kredit seringkali terdapat permasalahan dimana menurunnya sikap koperatif dari debitor, dan permasalahan lain yang juga bisa muncul dalam pelaksanaan kredit. Dalam hal demikian maka debitor dapat melakukan ingkar janji dalam pengembalian kredit.

Wanprestasi adalah suatu peristiwa atau keadaan, dimana debitor tidak memenuhi kewajiban prestasi perikatannya dengan baik, dan debitor punya unsur salah atasnya. ${ }^{24}$ Dalam hal debitor ingkar janji maka kreditor dapat meminta pemenuhan, sebagai berikut ${ }^{25}$ :

1) Memenuhi perikatan sesuai kesepakatan

2) Memenuhi perikatan dengan ganti rugi

3) Hanya memberikan Ganti kerugian

4) Pembatalan perikatan;

5) Pembatalan perikatan disertai dengan ganti rugi

Wanprestasi (ingkar janji) dapat terjadi dikarenakan debitor memang sengaja untuk tidak memenuhi janjinya atau dikarenakan adanya keadaan memaksa dari debitor. Istilah "keadaan memaksa", yang berasal dari istilah overmacht atau force majeure, dalam kaitannya dengan suatu perikatan atau kontrak tidak ditemui rumusannya secara khusus dalam Undang-Undang, tetapi disimpulkan dari beberapa pasal dalam $\mathrm{BW}^{26}$

\footnotetext{
${ }^{23}$ Agus Yudha Hernoko, Hukum Perjanjian (Asas Proporsionalitas Dalam Kontrak Komersil), Kencana, Jakarta: 2010, hlm 261.

${ }^{24}$ J. Satrio, Wanprestasi menurut KUHPerdata, Doktrin, dan Yurisprudensi, Citra Aditya Bakti, Bandung: 2010, hlm. 3

${ }^{25}$ R.Setiawan, Pokok-pokok Hukum Perikatan, Bina Cipta, Bandung: 1999, hlm. 18.

${ }^{26}$ J. Satrio, Op.Cit, h. 3
} 
Kredit bermasalah adalah suatu keadaan dimana debitor sudah tidak sanggup membayar sebagian atau keseluruhan kewajibannya kepada bank seperti yang telah diperjanjikan, atau telah ada suatu indikasi bahwa debitor tidak mampu melunasi utangnya. ${ }^{27}$ Didalam PBI No. 14/15/2012 tentang kualitas aktiva umum menggolongkan kualitas kredit menjadi 5 (lima) jenis, yaitu :

1) Lancar

2) Dalam perhatian khusus

3) Kurang lancar

4) Diragukan

5) Kredit macet

Suatu kredit dapat dikategorikan menjadi kredit yang bermasalah adalah apabila kondisi kredit tersebut berada dalam kategori kurang lancar, diragukan dan macet.

Upaya terhadap penanganan kredit bermasalah terdiri dari 2 (dua) cara, yaitu ${ }^{28}$ :

1) Upaya penyelamatan terhadap fasilitas kredit bermasalah.

Upaya penyelamatan terhadap fasilitas kredit bermasalah merupakan upaya restrukturisasi kredit sebagaimana diatur dalam PBI Nomor 14/15/PBI/2012 yang meliputi upaya Reschulding, Restructuring, dan Reconditioning. Berikut akan penulis jelaskan definisi dari masing-masing upaya restrukturisasi:

a) Reschulding merupakan perubahan syarat kredit yang hanya menyangkut jadwal pembayaran dan atau jangka waktu. Sehingga terhadap upaya ini bisa memperpanjang jangka waktu kredit atau angsuran bisa lebih ringan.

b) Reconditioning yaitu perubahan sebagian atau keseluruhan syarat-syarat kredit semisal perubahan jadwal pembayaran, jangka waktu dengan mengubah syarat seperti penurunan suku bunga atau pembebasan suku bunga.

c) Restructuring, dilakukan antara lain bisa meliputi penurunan suku bunga, perpanjangan jangka waktu kredit, penambahan fasilitas kredit, pengurangan tunggakan pokok dan bunga kredit atau konversi kredit menjadi penyertaan modal sementara. ${ }^{29}$

2) Upaya penyelesaian kredit bermasalah.

Jika kreditor telah melakukan upaya penyelamatan kredit, namun kreditor merasa tidak berhasil untuk melancarkan kembali kredit debitor, maka upaya penyelesaian kredit selanjutnya adalah dengan cara eksekusi objek jaminan dengan catatan bahwa objek jaminan tersebut dibebani lembaga jaminan sesuai dengan prosedur yang ditentukan oleh Undang-Undang. ${ }^{30}$ Namun sebelum melakukan

\footnotetext{
${ }^{27}$ Sutarno, Aspek-Aspek Hukum Perkreditan Pada Bank, Alfabeta, Bandung: 2004, hlm. 263

${ }^{28}$ Ibid, h 58

${ }^{29}$ Trisadini Prasastinah Usanti dan Nurwahjuni, Model Penyelesaian Kredit Bermasalah, Revka Petra Media, Surabaya: 2014, hlm. 60

${ }^{30}$ Ibid, h. 69.
} 
eksekusi pun pihak BCA lebih mendahulukan upaya-upaya lain. Upaya-upaya yang dilakukan BCA terhadap debitur yang wanprestasi, yaitu: ${ }^{31}$

a) Melakukan pendekatan dengan debitor, yaitu dengan cara berkomunikasi via telepon untuk menanyakan alasan kenapa debitor tidak melaksanakan atau memenuhi kewajibannya, sekaligus mengingatkan debitor akan kewajiban angsuran pokok dan bunga, jika adanya keterlambatan pembayaran, maka debitor wajib menyertakan pembayaran denda sebesar yang sudah ditentukan dalam perjanjian kredit.

b) Memberikan surat panggilan kepada debitor untuk datang ke kantor dimana pemberian kredit dilakukan, hal ini dilakukan agar pihak BCA secara langsung mengetahui keadaan dan kondisi debitor, kemudian pihak bank dan debitur dapat mencari solusi agar kredit tersebut dapat berjalan lancar.

3) Proses Eksekusi Hak Memakai Ruang (Stan Pasar) sebagai Objek Jaminan Fidusia

Dalam Pasal 29 ayat (1) Undang-Undang Fidusia, diatur mengenai cara eksekusi atas benda yang menjadi objek jaminan fidusia, yang dapat dilakukan dengan cara: ${ }^{32}$

a) Apabila debitor atau Pemberi Fidusia cidera janji, eksekusi terhadap Benda yang menjadi objek Jaminan Fidusia dapat dilakukan dengan cara:

(1) pelaksanaan titel eksekutorial sebagaimana dimaksud dalam Pasal 15 ayat (2) oleh Penerima Fidusia;

(2) penjualan benda yang menjadi objek Jaminan Fidusia atas kekuasaan Penerima Fidusia sendiri melalui pelelangan umum serta mengambil pelunasan piutangnya dari hasil penjualan;

(3) penjualan di bawah tangan yang dilakukan berdasarkan kesepakatan Pemberi dan Penerima Fidusia jika dengan cara demikian dapat diperoleh harga tertinggi yang menguntungkan para pihak.

b) Pelaksanaan penjualan sebagaimana dimaksud dalam ayat (1) huruf c dilakukan setelah lewat waktu 1 (satu) bulan sejak diberitahukan secara tertulis oleh Pemberi dan Penerima Fidusia kepada pihak-pibak yang berkepentingan dan diumumkan sedikitnya dalam 2 (dua) surat kabar yang beredar di daerah yang bersangkutan.

Eksekusi terhadap objek jaminan fidusia dapat dilakukan berdasarkan Sertifikat jaminan fidusia dikarenakan sertifikat jaminan fidusia juga mempunyai kekuatan eksekutorial (dapat dilakukan eksekusi) sama seperti putusan pengadilan yang telah memperoleh kekuatan hukum tetap, Maka terhadap pelaksanaan eksekusi objek jaminan fidusia berdasarkan grosse sertifikat jaminan fidusia atau dengan titel

\footnotetext{
${ }^{31}$ Wawancara dengan Staff Legal Bank Central Asia Cabang Surabaya, 5 November 2018.

${ }^{32}$ Undang-undang Republik Indonesia Nomor 42 Tahun 1999 tentang Jaminan Fidusia, Lembaran Negara Republik Indonesia Tahun 1999 Nomor 168, Tambahan Lembaran Negara Repubik Indonesia Nomor 3889
} 
eksekutorial sertifikat jaminan fidusia mengikuti pelaksanaan suatu putusan pengadilan.

Dalam Pasal 15 Undang-Undang Fidusia, mengandung 2 (dua) makna cara eksekusi, yaitu:

a) eksekusi menggunakan titel eksekutorial; atau

b) parate eksekusi.

\section{E. PENUTUP}

\section{Kesimpulan}

Kedudukan hak memakai ruang (stan) pasar merupakan hak sewa menyewa jika di tinjau lebih jauh dalam perjanjian hak memakai ruang, bahwa debitor hanya memiliki hak untuk menikmati atau memakai stan pasar yang di miliki oleh PT Porsam \& Co. Hak memakai ruang (stan) merupakan hak perorangan dan bukan merupakan hak kebendaan dengan pertimbangan bahwa hak memakai ruang tersebut lahir dari sewa menyewa yang ketentuanya diatur dalam buku III BW. Selain itu debitor menguasai benda yang disewakan hanya untuk menikmati bukan bertujuan untuk menjadikan stan pasar tersebut sebagai hak milik, sehingga sewa menyewa tidak melahirkan hak kebendaan. Namun jika ditinjau lebih jauh hak memakai ruang dapat dikategorikan sebagai benda dalam perspektif hukum jaminan, dikarenakan hak memakai ruang memenuhi syarat sebagai benda yang dapat dijaminkan yaitu memiliki nilai ekonomis dan dapat dialihkan meskipun dengan persetujuan pihak lain.

Mengingat hak memakai ruang merupakan hak perorangan, maka hak tersebut tidak dapat dijadikan objek jaminan dalam bentuk Gadai, Hipotek, Hak Tanggungan dan Fidusia. Adapun dalam praktiknya Bank banyak memaksakan hak memakai ruang yang dijadikan jaminan fidusia, maka hal tersebut tidak didukung dengan dasar hukum yang jelas dan dapat menimbulkan risiko bagi bank di kemudian hari. Wanprestasi terjadi dikarenakan BCA kurang menerapkan prinsip kehati-hatian dalam penyaluran kreditnya.

\section{Saran}

a. Perlu adanya kehati-hatian terhadap jaminan berupa hak memakai ruang (stand) pasar. Selain itu bank perlu lebih teliti dalam melakukan analisa kredit. Bahwa analisa kredit merupakan upaya preventif yang harus dilaksanakan secara profesional berdasarkan prosedur pemberian kredit yang dimiliki bank, jangan terjadi keteledoran bankers dalam malukan penelitian kredit karena dapat berakibat fatal. Tujuan bank harus melakukan analisis terhadap kredit dengan lebih hati-hati adalah untuk menilai kemampuan dan kesanggupan calon nasabah debitor untuk melunasi kewajiban atau utangnya. Sehingga penerapan prinsip 5C terhadap watak, kemampuan, modal, agunan, dan prospek usaha perlu dengan cermat dilaksanakan. 
b. Perlu dipersyaratkan adanya jaminan tambahan terhadap kredit atas hak memakai ruang (stand) pasar. Jaminan tambahan ini bisa lebih mengurangi risiko bank apabila debitor wanprestasi.

\section{DAFTAR PUSTAKA}

\section{Buku :}

Hasan, Djuhaendah dan Salmidjas Salam, Aspek Hukum Hak Jaminan Perorangan dan Kebendaan, Jakarta: 2000.

Hasbullah, Frieda Husni, Hukum Kebendaan Perdata Hak-Hak Yang Memberi Kenikmatan Jilid I, Cetakan KeIII, Ind-Hill Co, Jakarta: 2002.

Hernoko, Agus Yudha, Hukum Perjanjian (Asas Proporsionalitas Dalam Kontrak Komersil), Kencana, Jakarta: 2010.

Isnaeni, Moch, Hukum Jaminan Kebendaan (Eksistensi, Fungsi, dan Pengaturan), LaksBang Pressindo, Yogyakarta: 2016.

Marzuki, Peter Mahmud, Penelitian Hukum (Edisi Revisi), Kencana, Jakarta: 2005.

Prodjodikoro, Wirjono, Hukum Perjanjian dan Perikatan, Pradya Paramita, Jakarta: 1987.

Satrio,J, Wanprestasi menurut KUHPerdata, Doktrin, dan Yurisprudensi, Citra Aditya Bakti, Bandung: 2010.

Setiawan,R, Pokok-pokok Hukum Perikatan, Bina Cipta, Bandung: 1999.

Sofwan, Sri Soedewi Masjchoen, Hukum Jaminan di Indonesia Pokok-Pokok Hukum Jaminan dan Jaminan Perorangan, Liberty, Yogyakarta: 1980.

---------, Hukum Perdata: Hak Jaminan Atas Tanah, Liberty, Yogyakarta: 1981.

Subekti, Hukum Perjanjian, Intermasa, Jakarta: 1992.

Sutarno, Aspek-Aspek Hukum Perkreditan Pada Bank, Alfabeta, Bandung: 2004.

Taryana Soenandar, Prinsip-prinsip Unidroit, Sinar Grafika, Jakarta, 2004:

Tumbuan, Fred B.G, Mencermati Pokok-Pokok RUU Jaminan Fidusia, Newsletter Nomor 38 Tahun X, Yayasan Pusat Pengkajian Hukum, Jakarta: 1999.

Usanti, Trisadini Prasastinah dan Nurwahjuni, Model Penyelesaian Kredit Bermasalah, Revka Petra Media, Surabaya: 2014.

Usanti, Trisadini Prasastinah dan Leonora Bakarbessy, Hukum Jaminan, Revaka Petra Media, Surabaya: 2013.

Usman, Rachmadi, Hukum Jaminan Keperdataan, Sinar Grafika, Jakarta: 2016. 
Yulianto, Tanggung Jawab Notaris Dalam Membuat Akta Jaminan Kredit Perbankan, Mitra Usaha Abadi, Surabaya: 2004.

\section{Jurnal :}

Peter Mahmud Marzuki, "Penelitian Hukum”, Yuridika, No.2, Vol. 16, 2001.

-------, “Batas-Batas Kebebasan Berkontrak”, Yuridika, No. 3, Vol. 18, 2003.

Ridwan Khairandy, "Itikad Baik dalam Kebebasan Berkontrak", Pascasarjana Fakultas Hukum Universitas Indonesia, 2003.

\section{Perundang-Undangan :}

Undang-undang Republik Indonesia Nomor 42 Tahun 1999 tentang Jaminan Fidusia.

Undang-undang Republik Indonesia Nomor 10 Tahun 1998 tentang Perubahan Atas Undangundang Republik Indonesia Nomor 7 Tahun 1992 tentang Perbankan

Undang-Undang Republik Indonesia Nomor 4 Tahun 1996 Tentang Hak Tanggungan Atas Tanah Beserta Benda-Benda Yang Berkaitan Dengan Tanah.

Undang-undang Republik Indonesia Nomor 7 Tahun 1992 tentang Perbankan.

Undang-Undang Republik Indonesia Nomor 6 Tahun 1960 Tentang Peraturan Dasar PokokPokok Agraria.

Burgerlijk Wetboek (BW). 